\title{
Narrativity and Memory Analysis in Alzheimer's Disease
}

\author{
Cyril Hazif-Thomas', Remy Billon², Philippe Thomas ${ }^{3}$ \\ ${ }^{1}$ Department of Psychiatry for Elderly, CHRU de Brest, Bohars, France \\ ${ }^{2}$ Hospital St Louis, La Rochelle, France \\ ${ }^{3}$ Semiotics Research Center (CeReS. EA 3648), University of Limoges, Limoges, France \\ Email: cyril.hazifthomas@chu-brest.fr, remy.billon@orange.fr, philippe.thomas.2008@orange.fr
}

How to cite this paper: Hazif-Thomas, C., Billon, R. and Thomas, P. (2017) Narrativity and Memory Analysis in Alzheimer's Disease. Open Journal of Psychiatry, 7, 307-317. https://doi.org/10.4236/ojpsych.2017.74026

Received: July 26, 2017

Accepted: August 29, 2017

Published: September 1, 2017

Copyright (C) 2017 by authors and Scientific Research Publishing Inc. This work is licensed under the Creative Commons Attribution International License (CC BY 4.0).

http://creativecommons.org/licenses/by/4.0/ cc) (†) Open Access

\begin{abstract}
Alzheimer's Disease (AD) is a neurodegenerative illness with frequency of occurrence increasing with old age. If memory impairment setting progressively is here an element associated upfront, other neurocognitive troubles are also associated, for example, language impairment which can degenerate into aphasia. Aim of the study. To evaluate semantic and textual impairment in AD. Methods. Populations studied concerned 151 AD patients in consultation at Brest University Hospital. Certain sociodemographic data (sex, age, cultural levels) were collected as well as results from neuropsychological tests: (Folstein-MMSE; Dubois's 5-word test; fluencies, Dubois' s frontal test battery; Cornell's scale for depression; Barbizet's test, "The Lion's tale", for textual analysis. Demented patients were composed of 102 females and 49 males of average age $80.3 \pm 6.91$. All the tests, including the number of items memorized latterly in the Barbizet's test are impaired all the more by Folstein's test being altered. The formal fluency on demented patients is less impaired than the semantic lexical fluency test (scored respectively $5.74 \pm 1.09$ versus $4.41 \pm$ 2. $19 ; \mathrm{t}=5.60, p<0.01)$. The studied demented cohort shows more intrusions $(\mathrm{n}=36)$ than inversions in the delayed Lion's tale, whether for items or for episodes in which they occur $(n=19)$. The regressive PLS analysis shows that for the explanation of the overall scores to do with "The lion's tale", calculated later, only attainment of formal fluency has any notable influence (Regression coefficient $C R=0.224)$ or, more accessorily, the cultural level $(C R=0.12)$. Conclusions: Attainment of category fluency and patient culture levels has effects on narrativity.
\end{abstract}

\section{Keywords}

Alzheimer's Disease, Semiotics, Semantics, Textuality 


\section{Introduction}

Alzheimer's Disease (AD) is a neurodegenerative illness with frequency of occurrence increasing with old age [1] [2] [3] [4] [5]. If memory loss setting progressively in is here an element associated upfront, other neuro-psycho-cognitive troubles are also associated, as, for example, language impairment which can degenerate into aphasia [6]-[13]. Such disorders are not necessarily pronounced and do not necessarily kill the desire to communicate ("relational communicability") but they can occasionally be disabilitating in certain atypical forms known as logopenic. The disease from that point on is accompanied by deterioration of comprehension, speech, writing and reading [14]. Language dysfunction is one of the most significant symptoms in terms of incidence on textuality in $\mathrm{AD}$ [15] [16]. In the earliest stages, it is slight but it increases in time through foreseeable phases [17] [18] [19] [20]. Memory dysfunction also interferes with language possibilities [21]. Knowing the importance of both these components could help to prepare as well as possible for the consequences on the patient's social life [22] [23] [24].

Studies carried out on the language of the demented show at least relative and temporary conservation of language structure [25] [26] [27]. Emphasis is often placed on language conservation (phonology, syntax...) rather than "demented speech performance" [28] [29] [30]. The premises of approach of modern speech semiotics were already established as was the study of the mental thesaurus reflecting semantic competences, whether of the words used or the verbal symbols manipulated. However, if semantic studies have often been carried out, there are, to our knowledge, only a few on texts [25] [31] [32], other than those made to validate the Barbizet test used for this paper [33] [34]. The inability for a patient to express his or her own suffering [35] faced by a world that escapes his or her consciousness is a source of suffering both for the patient and his family [36] [37] [38]. Understanding language mechanisms is thus contingent to understanding the meaning of symptoms expressed by the patient's behaviour [22] [37] [39]. Language dysfunction, communication distortion, and mutual incomprehension are part of the hidden causes that sometimes lead formal or informal (family) care-givers into painful situations [40] [41]: psychological or psychiatric difficulties in the families, unspoken discord, financial problems arising from errors made by the aging patient as well, unfortunately, as the tactlessness or unscrupulousness of some people... What is at stake here is important as usual [42], and consequently we have tried, in this monocentric prospective observation and study to evaluate semantic and textual dysfunction in AD.

\section{Methods}

\subsection{Population}

The cohort studied were old demented patients living at home with $\mathrm{AD}$ followed since at least 3 months by gerontopsychiatrics for cognitive, behavioural and memory dysfunction. During a gerontopschiatric interview, patients and 
accompanying family were informed completely and loyally and in understandable language how the study would be carried out. With the agreement of the patient and assistant, the results of the neuropsychological tests were computer recorded anonymously. The study protocol was ethically reviewed and approved by Hospital of Brest ethics committee. Computing procedures for data capture and processing followed the recommendations of the French National Commission on Computer Technology and Freedom.

\subsection{Criteria for Inclusion}

Criteria were determined for inclusion based from AD patients, (MMSE > 10) [43], having given written consent together with their family assistants, to take part in this study validated by the Hospital of Brest ethics committee. Only those patients still capable of understanding the instructions for the Barbizet's test, showing symptoms of Alzheimer dementia, i.e. without massive memory impairment and capable of asserting their consent and assent during the test and fit and able in the eyes of the Law, were included. Patients inability to understand information relating to the study, their inability to choose whether or not to take part, or the possible opposition of their family accompanying person as a criterion were decisive for non-inclusion of such patients. Population number reflects the demented persons follow-up during the period of one year of this study.

\subsection{Used Scales}

Semantic memory is the memory necessary for language manipulation and not over vulnerable to amnesia [44]. To evaluate semantic and textual disorders in a cohort of $\mathrm{AD}$ patients, tests were routinely recorded with memory consultation, and from a few sociodemographic data (sex, age, cultural level estimated by the number years of schooling: 1 = illiterate; 2 = can read and write; $3=$ six years schooling; $4=11$ years schooling; 5 = more than 11 years schooling). The following are the tests customarily carried out under consultation: Folstein Test (MMSE) [43], Dubois's 5-word test (D5WT) [45], formal fluency (Number of animals mentioned in one minute), semantic lexical fluency (number of words beginning with $\mathrm{L}$ named in one minute) [45], DFB (Dubois's Frontal Battery) [46], Cornell's scale (Depression) [47], Barbizet's test [33] or “The lion's tale".

\subsection{The "Lion's Tale"}

The "Lion's tale" (presented Table 1) must be read by the examiner slowly. The subject must be informed that it is a long story, the point of which is to evaluate his memory capacity. He must be told it is not a matter of repeating the story word for word but just recalling its main lines and as many details as possible. Barbizet recommended an immediate application, an immediate recall, then a delayed recall. In practice, in the present framework, the text was read out at the beginning of the consultation, followed by an immediate recall and then a delayed recall towards the end of the consultation, that is, about one hour later. 
Table 1. "The lion's tale" [33]. Text and sequential organization.

\begin{tabular}{cc}
\hline Episode & \multicolumn{1}{c}{ Text } \\
\hline Escape & $\begin{array}{c}\text { A lion named Sultan, escaped from its cage, } \\
\text { by the door badly closed by a careless guard } \\
\text { The crowd of the visitors numerous on } \\
\text { Sunday runs away towards the nearby buildings } \\
\text { Woman and child } \\
\text { A woman, dressed in blue which held in the arms } \\
\text { her one-year-old child dropped him. The lion seizes it } \\
\text { The woman in tears retraced his steps, } \\
\text { and begged the lion to return her young } \\
\text { Resolution }\end{array} \quad$ The animal looked at her for a long time, fixedly, and \\
& finally released the child without having made for him the slightest evil \\
\hline
\end{tabular}

\subsection{Statistics}

So, this short text with 22 sub-items learned sequential, is recalled immediately and repeated later. The items can be organised according to the author of the test into five episodes: escape, crowd movement, woman and child, deal, resolution (Table 2). Barbizet shows up things from the tale forgotten, intrusions and inversions to be noted. These data will be compared with that of the neurosychological tests. Statistics were established with a SAS programme by a bio-statistician, Dr R. Billon. Tests selected were Chi2, Student (un-paired), Pearson's correlations, Partial Least Squares regression, chosen to reduce risks of collinearity [48]. With a classic linear model, collinearity between explanatory variables does make the model unstable and influence the results, making them uncertain.

\section{Results}

Hundred and fifty-one patients, living at home, on their own or with their families, were included in the study. No cases were recorded of refusal to participate in the study or to having the results observed computerised anonymously. The cohort of demented patients is made up of 102 females and 49 males of average age 80.3 years \pm 6.91 . Table 2 resumes the main results observed. Average characteristics did not differ statistically between the males and the females. The formal fluency on demented patients is less impaired than the semantical lexical fluency test (scored respectively $5.74 \pm 1.09$ versus $4.41 \pm 2$. 19; $\mathrm{t}=5.60, p<$ $0.01)$.

Table 3 shows results obtained from the recall of "the lion's tale". Results to do with the episodes in the tale have a bearing on the delayed recall. All but one of the patients can remember the story was about a lion; $67 \%$ subsequently remembered that the animal brought back the child totally unharmed and $47 \%$ that the tale involved a woman. The studied population showed more cases of intrusion $(\mathrm{n}=36)$ than inversion in the later narration, whether items or episodes combining the two $(\mathrm{n}=19)$. Nearly all the inversions were by patients whose MMSE was below 19 and the intrusions by patients whose MMSE was below 15 (Figure 1). Admittedly, intrusions are specific to AD pathology, where 


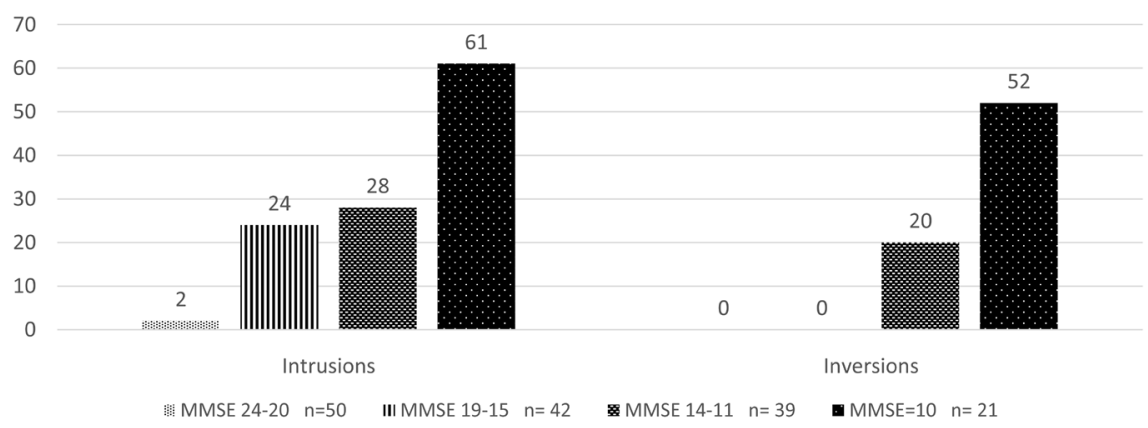

Figure 1. Percentage of inversions $(n=19)$ and intrusions- $n=36)$ according to the MMSE. Chi2 with Yate's correction: $p<0.05$ for the number of intrusions or of inversions, cut-off MMSE < 15 .

Table 2. Sociodemographic data and results in the diverse tests $(\mathrm{N}=151)$. DFB: Dubois's Frontal Battery; D5WT: Dubois's 5 words test.

\begin{tabular}{cccccccc}
\hline Age & $\begin{array}{c}\text { Cultural } \\
\text { level }\end{array}$ & MMSE & DFB & Cornell & D5WT & $\begin{array}{c}\text { Semantic } \\
\text { lexical } \\
\text { Fluency }\end{array}$ & $\begin{array}{c}\text { Formal } \\
\text { Fluency }\end{array}$ \\
\hline $80.3 \pm 6.9$ & $2.82 \pm 0.50$ & $16.5 \pm 5.1$ & $11.3 \pm 4.5$ & $10.6 \pm 4.2$ & $4.58 \pm 1.1$ & $4.41 \pm 2.2$ & $5.7 \pm 1.1$ \\
\hline
\end{tabular}

Table 3. "The Lion's tale": Global Score and episodes (Immediate and delayed recall) in the Barbizet's test $(\mathrm{n}=151)$.

\begin{tabular}{|c|c|c|c|c|c|c|}
\hline $\begin{array}{c}\text { Immediate } \\
\text { recall } \\
\text { Usual } \\
\text { score }=22\end{array}$ & $\begin{array}{c}\text { Delayed } \\
\text { recall } \\
\text { Usual } \\
\text { score }=22\end{array}$ & $\begin{array}{c}\text { Episode } \\
\text { Escape } \\
\text { Usual } \\
\text { score }=6\end{array}$ & $\begin{array}{c}\text { Episode } \\
\text { Crowd } \\
\text { movement } \\
\text { Usual score = } 3\end{array}$ & $\begin{array}{c}\text { Episode } \\
\text { Women } \\
\text { child Usual } \\
\text { score }=6\end{array}$ & $\begin{array}{c}\text { Episode } \\
\text { deal } \\
\text { Usual } \\
\text { score }=2\end{array}$ & $\begin{array}{c}\text { Episode } \\
\text { resolution } \\
\text { Usual } \\
\text { score }=5\end{array}$ \\
\hline $6.6 \pm 2.2$ & $5.5 \pm 3.1$ & $1.4 \pm 1.3$ & $0.1 \pm 0.3$ & $0.4 \pm 0.7$ & $0.7 \pm 0.7$ & $0.8 \pm 0.5$ \\
\hline
\end{tabular}

we find their greatest occurrence. However, these results could suggest that intrusions are essentially linked to executive problems concerning response control. When referring to patients' dysexecutive syndrome (DFT $<13 ; n=77)$ it is to be remarked that, overall, inversions occur in the deficient group (Table 4). It is also to be remarked that inversions are observed to be more precocious when disease deteriorates textuality and prevents the pragmatics of communication. MMSE for the executive syndrome sub-group $(\mathrm{n}=77)$ was $11.9 \pm 2.9$ against $20.9 \pm 2.6$ for the less seriously affected group $(n=74)$

Table 5 shows the correlation matrix for the various parameters studied. Many parameters are correlated whence the choice of PLS for regression analysis. Table 6 shows this regressive analysis on standardized variables. The factor studied is the overall score for Barbizet's test with the model including the variables of the previous figure.

The formal fluency remains the one that most influences the overall score with a coefficient of 0.224 . The higher it is, the greater the success in the test and this influence is almost three times that of the lexical memory. Then, we will retain cultural level and, more accessorily, age, but all the others are less interesting. 
Table 4. Number of intrusions and inversions according to the dysexecutive syndrome estimated by the score at the DFB (Maximum score in the DFB when there is no dysexecutive syndrome: 18). DFB: Dubois's Frontal Battery.

\begin{tabular}{ccc}
\hline & $\mathrm{DFB} \geq 13(\mathrm{n}=74)$ & $\mathrm{DFB}<13(\mathrm{n}=77)$ \\
\hline Intrusions & 7 & 29 \\
Inversions & 0 & 19 \\
\hline
\end{tabular}

Table 5. Correlations between the data in the various tests in the studied population. ${ }^{*}=p$ $<0.05$. DFB: Dubois's Frontal Battery; D5WT: Dubois's 5 words test. Lion's tale: Global Score (Delayed recall) in the Barbizet's test.

\begin{tabular}{|c|c|c|c|c|c|c|c|c|c|c|}
\hline & MMSE & DFB & D5WT & Cornell & $\begin{array}{c}\text { Semantic } \\
\text { lexical } \\
\text { Fluency }\end{array}$ & $\begin{array}{l}\text { Formal } \\
\text { Fluancy }\end{array}$ & Age & Gender & $\begin{array}{c}\text { Cultural } \\
\text { Level }\end{array}$ & $\begin{array}{c}\text { Lion's } \\
\text { tale }\end{array}$ \\
\hline MMSE & 1.0 & & & & & & & & & \\
\hline DFB & $0.97^{\star}$ & 1.0 & & & & & & & & \\
\hline D5WT & $0.86^{*}$ & $0.74^{*}$ & 1.0 & & & & & & & \\
\hline Cornell & -0.08 & 0.11 & -0.30 & 1.00 & & & & & & \\
\hline $\begin{array}{c}\text { Semantic } \\
\text { lexical } \\
\text { Fluency }\end{array}$ & $0.87^{\star}$ & $0.84^{*}$ & $0.78^{*}$ & -0.17 & 1.0 & & & & & \\
\hline $\begin{array}{l}\text { Formal } \\
\text { Fluancy }\end{array}$ & $0.82^{*}$ & $0.80^{*}$ & 0.71 & 0.03 & $0.80^{*}$ & 1.0 & & & & \\
\hline Age & -0.27 & -0.29 & -0.17 & -0.07 & -0.29 & -0.21 & 1.0 & & & \\
\hline Gender & -0.10 & -0.08 & -0.12 & 0.03 & -0.08 & -0.09 & 0.10 & 1.0 & & \\
\hline $\begin{array}{c}\text { Cultural } \\
\text { Level }\end{array}$ & 0.18 & 0.13 & 0.22 & -0.16 & 0.13 & 0.15 & -0.04 & -0.15 & 1.0 & \\
\hline Lion's tale & $0.51^{*}$ & $0.49^{*}$ & $0.46^{\star}$ & -0.04 & $0.50^{*}$ & $0.50^{*}$ & -0.23 & -0.06 & -0.01 & 1.0 \\
\hline
\end{tabular}

Table 6. Estimate of Regression Coefficients. Regression PLS. Studied factor: Global Score (Delayed recall) in the Barbizet's test. Model including the variables of the previous picture. DFB: Dubois's Frontal Battery; DWT: Dubois's 5 words test.

\begin{tabular}{ccc}
\hline & Estimate & Standard error \\
\hline Constant & 0.0 & 0.071 \\
MMSE & 0.085 & 0.070 \\
Formal fluencies & 0.224 & 0.129 \\
DFB & 0.084 & 0.112 \\
D5WT & 0.090 & 0.126 \\
Cornell & -0.050 & 0.093 \\
Semantic lexical Fluencies & 0.085 & 0.176 \\
Age & -0.108 & 0.085 \\
Gender & -0.017 & 0.071 \\
Cultural level & 0.117 & 0.089 \\
\hline
\end{tabular}




\section{Discussion}

We are presenting here the results of a preliminary study on narrativity in $A D$ based on consultation with the patients in an old-age psychiatric department. The very nature of the department explains the old age of those recruited. MMSE worsening in certain patients is an approach making their understanding of the text difficult and even the value of their consent. The aid of their family accompanying person was then precious and all the tests were those habitually carried out regularly on this type of patient under the specialised consultation of our establishment.

The correlation matrix in Table 5 evokes another aspect of this study: the serious collinearity between the variables observed that we have not wanted to push aside because language dysfunction can be explained by many factors, cognitive or not. This has encouraged us to use a Partial Least Squares regression on all the variables studied.

The executive disorders studied by the DFB and cognitive disorders estimated by the MMSE are strongly correlated, also it is difficult to know which verbal consequences result specifically from one of these factors or from the other one. The threshold of 13 was however chosen on one hand so that the sub-populations were balanced, and on the other hand for a clear cut-off with the existence or not of a dysexecutive syndrome connected to frontal disorders. The presence of a such dysexecutive syndrome, in case of late depression (with or without dementia), impacts on the cognitive status [49]. The depressive elderly present frequently changes of the verbal fluencies and the deficits of planning connected to frontal disorders [50]. The scores on the scale of Cornell are weak in the population of the study presented here. The depression is frequent in particular when the dementia progresses, in particular when the elderly live in nursing home [47]. The elderly included in this study lived at home. The scores on the scale of Cornell presented here are low (Table 2: $11.3 \pm 4.5$, depression's threshold value $>8$ ).

The non-mnesic disorders (linguistic, visual, behavioral) have to remind atypical Alzheimer's diseases or other types of dementia, and should lead to a search for an association with a frontotemporal degeneration what today is the object of link between neurology and psychiatry [51].

We shall notice in this study, the important progress of the textual disorders observed through the score in the delayed recall in «the lion's tale ", all the more degraded that the cognitive disorders are installed. Intrusions and inversions can result from cognitive disorders as well as from related executive disorders. Formal fluencies weigh in a significant way but in a modest way on the studied model of regression $(\mathrm{CR}=0.224)$, so with a lesser scale the cultural level $(\mathrm{CR}=$ 0.117), the cognitive disorders of the dementia as well as the linguistic disorders being classically modulated by this one [29] [43].

Even if the PLS model PLS is more influenced by the formal fluency the lexical semantic fluencies are more altered than the formal fluency (Table 2). Find a 
word beginning with a letter (" $L$ " in French, "S" in English, for reasons of frequency of use of this letter in the beginning of a word) require a strategy of recovery based on the abstract lexical representation [52]. The degradation of the formal fluency testifies of a more important disorganization of the functions of the language

The concrete items with strong emotional connotation in "the lion's tale" (A woman, a child, a lion...) are better memorized than more secondary (For a long time, fixedly...): even there the emotion appears clearly as the "power steering" of the reason and the memory.

\section{Conclusion}

The lexical semantic fluency is more altered than the formal fluency in the Alzheimer's disease. The degradation of the formal fluency testifies an important disorganization of the functions of the language. The fluencies impairments have an impact on the memorization of a text, in parallel with developments of cognitive disorders. The cultural level also influences the narrative skills of the patient which remain sensitive to the emotional aspect of a story when assessed in a memory testing. This emotional mobilization is probably an interesting way of motivation in speech therapy, to lead preventively or to maintain lexical and textual capacities in the Alzheimer's disease.

\section{Financing}

No personal financing sought for this study.

\section{Conflicts}

No conflicts of interest declared by its authors.

\section{References}

[1] Dubois, B. (2013) A New Definition for Alzheimer's Disease. Bulletin de I Academie Nationale de Medecine, 197, 143-153; discussion 153-146.

[2] Thomas, P., Clement, J.-P., Hazif-Thomas, C. and Leger, J.-M. (2001) Family, Alzheimer's Disease and Negative Symptoms. Int J Geriatr Psychiatry, 16, 192-202. https://doi.org/10.1002/1099-1166(200102)16:2<192::AID-GPS301>3.0.CO;2-Y

[3] Thomas, P., Montagne, B., Chantoin, S., Belmin, S., Clement, J., et al. (2001) Alzheimer's Disease and Consciousness of the Disorder by the Sick Person. Consequences for the Main Caregiver. PIXEL Study. Revue Neurologique, 157, 4-13.

[4] Holmes, D. (2014) Bruno Dubois: Transforming the Diagnosis of Alzheimer's Disease. The Lancet Neurology, 13, 541. https://doi.org/10.1016/S1474-4422(14)70106-1

[5] Bird, T.D. (1993) Alzheimer Disease Overview. Gene Reviews ${ }^{\circledast}$, Seattle, WA, i-ii. http://www.ncbi.nlm.nih.gov/books/NBK1161/

[6] Gewirth, L.R., Shindler, A.G. and Hier, D.B. (1984) Altered Patterns of Word Associations in Dementia and Aphasia. Brain and Language, 21, 307-317. https://doi.org/10.1016/0093-934X(84)90054-3 
[7] Nicholas, M., Obler, L.K., Albert, M.L. and Helm-Estabrooks, N. (1985) Empty Speech in Alzheimer's Disease and Fluent Aphasia. Journal of Speech, Language, and Hearing Research, 28, 405-410. https://doi.org/10.1044/jshr.2803.405

[8] Emery, O.B. (1985) Language and Aging. Experimental Aging Research, 11, 3-60. https://doi.org/10.1080/03610738508259280

[9] Fischer, P., Gatterer, G., Marterer, A. and Danielczyk, W. (1988) Nonspecificity of Semantic Impairment in Dementia of Alzheimer's Type. Archives of Neurology, 45, 1341-1343. https://doi.org/10.1001/archneur.1988.00520360059012

[10] Shuttleworth, E.C. and Huber, S.J. (1988) The Naming Disorder of Dementia of Alzheimer Type. Brain and Language, 34, 222-234. https://doi.org/10.1016/0093-934X(88)90134-4

[11] Huff, F.J., Mack, L., Mahlmann, J. and Greenberg, S. (1988) A Comparison of Lexical-Semantic Impairments in Left Hemisphere Stroke and Alzheimer's Disease. Brain Lang, 34, 262-278.

[12] Emery, O.B. and Breslau, L.D. (1988) The Problem of Naming in SDAT: A Relative Deficit. Experimental Aging Research, 14, 181-193.

https://doi.org/10.1080/03610738808259746

[13] Verma, M. and Howard, R.J. (2012) Semantic Memory and Language Dysfunction in Early Alzheimer's Disease: A Review. International Journal of Geriatric Psychiatry, 27, 1209-1217. https://doi.org/10.1002/gps.3766

[14] Noble, K., Glosser, G. and Grossman, M. (2000) Oral Reading in Dementia. Brain Lang, 74, 48-69. https://doi.org/10.1006/brln.2000.2330

[15] Stilwell, B.L., Dow, R.M., Lamers, C. and Woods, R.T. (2015) Language Changes in Bilingual Individuals with Alzheimer's Disease. International Journal of Language \& Communication Disorders, 51, 113-127.

[16] Hassenstab, J., Monsell, S.E., Mock, C., Roe, C.M., Cairns, N.J., et al. (2015) Neuropsychological Markers of Cognitive Decline in Persons with Alzheimer Disease Neuropathology. Journal of Neuropathology \& Experimental Neurology, 74, 1086-1092. https://doi.org/10.1097/NEN.0000000000000254

[17] Troster, A.I., Salmon, D.P., McCullough, D. and Butters, N. (1989) A Comparison of the Category Fluency Deficits Associated with Alzheimer's and Huntington's Disease. Brain Lang, 37, 500-513.

[18] Smith, S.R., Murdoch, B.E. and Chenery, H.J. (1989) Semantic Abilities in Dementia of the Alzheimer Type. 1. Lexical Semantics. Brain Lang, 36, 314-324.

[19] Lang, C.J. (1989) Continuous Figure Recognition in Dementia and Unilateral Cerebral Damage. Neuropsychologia, 27, 619-628.

[20] Arroyo-Anlloa, E.-M., Ingrand, P. and Gil, R. (2012) Improvement of Semantic Categorization through Procedural Learning in Alzheimer's Disease. Journal of Alzheimer's Disease, 30, 121-129.

[21] Reilly, J., Rodriguez, A.D., Lamy, M. and Neils-Strunjas, J. (2010) Cognition, Language, and Clinical Pathological Features of Non-Alzheimer's Dementias: An Overview. Journal of Communication Disorders, 43, 438-452.

[22] Cummings, J., Mintzer, J., Brodaty, H., Sano, M., Banerjee, S., et al. (2015) Agitation in Cognitive Disorders: International Psychogeriatric Association Provisional Consensus Clinical and Research Definition. International Psychogeriatrics, 27, 7-17. https://doi.org/10.1017/S1041610214001963

[23] Hazif-Thomas, C. and Thomas, P. (2011) The Care at the Risk of the Alzheimer's Disease: Greater Guidance or Self-Determination of the Caregivers? La Revue Francophone de Gériatrie et de Gérontologie, 18, 194-199. 
[24] Hazif-Thomas, C., Thomas, P., Tritschler-LeMaitre, M.H. and Walter, M. (2012) Limits and Legal Ambiguities of the Role of the Family Caregivers. Encephale, 38, 411-417.

[25] Irish, M., Kamminga, J., Addis, D.R, Crain, S., Thornton, R., et al. (2015) "Language of the Past" Exploring Past Tense Disruption during Autobiographical Narration in Neurodegenerative Disorders. Journal of Neuropsychology, 10, 295-316.

[26] Leyton, C.E., Savage, S., Irish, M., Schubert, S., Piguet, O., et al. (2014) Verbal Repetition in Primary Progressive Aphasia and Alzheimer's Disease. Journal of Alzheimer's Disease, 41, 575-585.

[27] Bird, H., Lambon Ralph, M.A., Patterson, K. and Hodges, J.R. (2000) The Rise and Fall of Frequency and Imageability: Noun and Verb Production in Semantic Dementia. Brain Lang, 73, 17-49. https://doi.org/10.1006/brln.2000.2293

[28] Altmann, L.J. and McClung, J.S. (2008) Effects of Semantic Impairment on Language Use in Alzheimer's Disease. Seminars in Speech and Language, 29, 18-31. https://doi.org/10.1055/s-2008-1061622

[29] Arroyo-Anllo, E.-M., Beauchamps, M., Ingrand, P., Neau, J-P. and Gil, R. (2013) Lexical Priming in Alzheimer's Disease and Aphasia. European Neurology, 69, 360-365. https://doi.org/10.1159/000347223

[30] Benke, T., Andree, B., Hittmair, M. and Gerstenbrand, F. (1990) Speech Changes in Dementia. Fortschritte Der Neurologie-Psychiatrie, 58, 215-223. https://doi.org/10.1055/s-2007-1001185

[31] Davis, B.H. and Maclagan, M. (2009) Examining Pauses in Alzheimer's Discourse. American Journal of Alzheimer's Disease \& Other Dementiasr, 24, 141-154. https://doi.org/10.1177/1533317508328138

[32] Kumfor, F., Hodges, J.R. and Piguet, O. (2014) Ecological Assessment of Emotional Enhancement of Memory in Progressive Nonfluent Aphasia and Alzheimer's Disease. Journal of Alzheimer's Disease, 42, 201-210.

[33] Barbizet, J. and Truscelli, D. (1965) Lion's Tale. Comments on Fabulation. Semaine des Hôpitaux, 28, 1688-1694.

[34] Croisile, B., Astier, J.-L., Beaumont, C. and Mollion, H. (2010) Validation of the Rapid B Attery of Denomination (BARD) in 382 Controls and 1004 Patients of a Memory Clinic. Revue Neurologique, 166, 584-593.

[35] Eisfeld, I.S. (2004) Semantic Dementia: Clinical Profile and Cognitive-Neuropsychological Relevance. Fortschritte Der Neurologie-Psychiatrie, 72 , 383-396. https://doi.org/10.1055/s-2004-818393

[36] Thomas, P., Ingrand, P., Lalloue, F., Hazif-Thomas, C., Billon, R., et al. (2004) Reasons of Informal Caregivers for Institutionalizing Dementia Patients Previously Living at Home: The Pixel Study. International Journal of Geriatric Psychiatry, 19, 127-135. https://doi.org/10.1002/gps.1039

[37] Thomas, P., Lalloue, F., Preux, P.-M., Hazif-Thomas, C., Pariel, S., et al. (2006) Dementia Patients Caregivers Quality of Life: The PIXEL Study. International Journal of Geriatric Psychiatry, 21, 50-56. https://doi.org/10.1002/gps.1422

[38] Chantoin, S., Hazif-Thomas, C., Billon, R. and Thomas, P. (2001) Scale of Appreciation of the Lack of Motivation Construction at the Elderly Person. Encephale, 27, 450-458.

[39] Belzil, G. and Vezina, J. (2015) Impact of Caregivers' Behaviors on Resistiveness to Care and Collaboration in Persons with Dementia in the Context of Hygienic Care: An Interactional Perspective. International Psychogeriatrics, 27, 1861-1873. https://doi.org/10.1017/S104161021500099X 
[40] Uflacker, A., Edmondson, M.C., Onyike, C.U. and Appleby, B.S. (2015) Caregiver Burden in Atypical Dementias: Comparing Frontotemporal Dementia, Creutzfeldt-Jakob Disease, and Alzheimer's Disease. International Psychogeriatrics, 1-5.

[41] Dooley, J., Bailey, C. and McCabe, R. (2015) Communication in Healthcare Interactions in Dementia: A Systematic Review of Observational Studies. International Psychogeriatrics, 27, 1277-1300. https://doi.org/10.1017/S1041610214002890

[42] Klimova, B., Maresova, P., Valis, M., Hort, J. and Kuca, K. (2015) Alzheimer's Disease and Language Impairments: Social Intervention and Medical Treatment. Clinical Interventions in Aging, 10, 1401-1407.

[43] Folstein, M.F., Folstein, S.E. and McHugh, P.R. (1975) "Mini-Mental State". A Practical Method for Grading the Cognitive State of Patients for the Clinician. Journal of Psychiatric Research, 12, 189-198.

[44] Tulving, E. (1995) Organisation of Memory: Quo Vadis? The Cognitive Neurosciences Mass. MIT Press MS Gazzaniga, Cambridge, 839-847.

[45] Dubois, B. (2001) 5 Words Test. Technical Recommendations. Neurologie-PsychiatrieGériatrie, 40-42.

[46] Dubois, B., Slachevsky, A., Litvan, I. and Pillon, B. (2000) The FAB: A Frontal Assessment Battery at Bedside. Neurology, 55, 1621-1626. https://doi.org/10.1212/WNL.55.11.1621

[47] Alexopoulos, G.S., Abrams, R.C., Young, R.C. and Shamoian, C.A. (1988) Cornell Scale for Depression in Dementia. Biological Psychiatry, 23, 271-284.

[48] Tenenhaus, M., Esposito Vinzi, V., Chatelinc, Y.-M. and Lauro, C. (2005) PLS Path Modeling. Computational Statistics \& Data Analysis, 48, 159-205.

[49] Hazif-Thomas, C., Reber, G., Bonvalot, T. and Thomas, P. (2005) Dysexecutive Syndrome and Late Life Depression. Annales Medico-Psychologiques, 163, 569-576.

[50] Elliott, R., Sahakian, B.J., Herrod, J.J., Robbins, T.W. and Paykel, E.S. (1997) Abnormal Response to Negative Feedback in Unipolar Depression: Evidence for a Diagnosis Specific Impairment. Journal of Neurology, Neurosurgery, \& Psychiatry, 63, 74-82. https://doi.org/10.1136/jnnp.63.1.74

[51] Lagarde, J. and Sarazin, M. (2016) Reconciliating Neurology and Psychiatry: The Prototypical Case of Frontotemporal Dementia. Encephale.

[52] Lee, H. (2012) Langage et Maladie d'Alzheimer: Multidimensional Analysis of a Pathological Speech. State Doctorate. University Paul-Valéry, Montpellier 3, https://tel.archives-ouvertes.fr/tel-00812618v1/document:198-199 